\title{
Vitamin D gene polymorphisms are associated with type 1 diabetes mellitus in Korean youth
}

\author{
Hyo-Kyoung Nam, Young Jun Rhie, Kee-Hyoung Lee \\ From 7th APPES Biennial Scientific Meeting \\ Nusa Dua, Bali. 14-17 November 2012
}

Vitamin D deficiency is reported in patients with type 1 diabetes mellitus (T1DM). Allelic variations in the gene associated with vitamin $\mathrm{D}$ metabolism were reported to play a role in glucose metabolism. CYP2R1 and CYP27B1 gene polymorphisms were investigated as a candidate gene for T1DM in Korean youth.

We measured serum level of 25-hydroxyvitamin D and 1,25-dihydroxyvitamin D in 217 subjects and defined vitamin $\mathrm{D}$ deficiency as 25 -hydroxyvitamin $\mathrm{D}$ level below $20 \mathrm{ng} / \mathrm{ml}$. Five single nucleotide polymorphisms (SNPs) in the CYP2R1 gene and three SNPs in the CYP27B1 gene were examined in 92 patients with T1DM and 125 controls. The frequency of A/G alleles of the rs 12794714 was $35.9 \% / 64.1 \%$ and $46.0 \% / 54.0 \%$ in T1DM youth and controls, respectively $(\mathrm{p}=0.034)$. The G/A alleles of the rs 10766196 was $37.0 \% / 63.0 \%$ and $46.0 \% / 54.0 \%$ in T1DM youth and controls, respectively $(\mathrm{p}=0.059)$. We observed that the GG homozygous genotype of rs12794714 and AA homozygous genotype of rs10766196 were more prevalent in T1DM youth than in controls $(42.4 \%$ vs. $29.6 \%, \mathrm{p}=0.051$ and $41.3 \%$ vs. $29.6 \%, p=0.073$, respectively). The prevalence of vitamin D deficiency was considerably higher in T1DM youth with 'G' allele of rs12794714 and 'A' allele of rs12794714.

Polymorphisms in CYP2R1 gene are associated with susceptibility to T1DM in Korean youth. The pathophysiological mechanisms remain unexplained, but they could be related to an etiological role for vitamin D deficiency in T1DM.

Published: 3 October 2013

Department of Pediatrics, College of Medicine, Korea University, Seoul, Republic of Korea

C Biomed Central

@ 2013 Nam et al; licensee BioMed Central Ltd. This is an Open Access article distributed under the terms of the Creative Commons Attribution License (http://creativecommons.org/licenses/by/2.0), which permits unrestricted use, distribution, and reproduction in any medium, provided the original work is properly cited.
doi:10.1186/1687-9856-2013-S1-P24

Cite this article as: Nam et al: Vitamin D gene polymorphisms are associated with type 1 diabetes mellitus in Korean youth. International Journal of Pediatric Endocrinology 2013 2013(Suppl 1):P24.

Submit your next manuscript to BioMed Central and take full advantage of:

- Convenient online submission

- Thorough peer review

- No space constraints or color figure charges

- Immediate publication on acceptance

- Inclusion in PubMed, CAS, Scopus and Google Scholar

- Research which is freely available for redistribution Submit your manuscript at
www.biomedcentral.com/submit C Biomed Central 